\title{
10
}

\section{Geographies of Connection and Disconnection: Narratives of Seafaring in Lý Sơn}

\author{
Edyta Roszko
}

An unexpected sea breeze coming from the north on a Friday morning in June 2014 promised a bit of respite from the heat on Lý Sơn Island, located about 30 kilometres offshore from Quảng Ngãi Province in Vietnam and 123 nautical miles (ca. $228 \mathrm{~km}$ ) from the Paracel Archipelago. ${ }^{1}$ Every Friday and Saturday, I sipped my morning coffee in one of the local café shops near the port, updated myself on village affairs, and observed the stream of Vietnamese tourists flowing from the ship onto the seashore. Most of them were taken by cars to newly built hotels and small guesthouses that quickly filled up with organised tour groups, mainly from Hà Nội and Hồ Chí Minh City. Due to China's repeated confiscation of Lý Sơn's fishing vessels and harassment of their fishermen, Lý Sơn Island had become

\footnotetext{
1 The research for this chapter was funded by the People Programme (Marie Curie Actions) of the European Union's Seventh Framework Programme (FP7/2007-2013) under REA grant agreement no PIEF-GA-2012-326795. This paper is also partially based on a 12-month period of ethnographic fieldwork conducted in 2006-07 in Lý Sơn, which received financial support from the Max Planck Institute for Social Anthropology in Halle. The author also wishes to acknowledge support from the 2014 Vietnam Update organisers and particularly thanks Philip Taylor for his close reading and many invaluable comments that have greatly improved this chapter. Oscar Salemink, Li Tana, and the two anonymous readers also deserve special mention for their thoughtful comments on the chapter.
} 
a putative symbol of 'defending sovereignty' over the 'East Sea' - the Vietnamese name for the South China Sea (Roszko 2015) and became a destination for tourists eager to show their solidarity with the islanders who bore the brunt of the defence of the nation's sovereignty.

A group of eight women in their late 50s who I met that Friday serve as an example of a new style of patriotic tourism in coastal areas that has become increasingly popular among urban Vietnamese. This kind of tourism - which is both secular and ritual — involves travelling to the country's islands in order to experience the sea environment, food, and patriotism through entertainment and commemorative activities in spaces designated and designed by the state for remembering. The eight retired correctional police officers (công an điều chình) from Hà Nội, Nha Trang, Buôn Ma Tuột, and Pleiku arranged with Lý Sơn authorities to meet with selected 'poor fishing families' and award a small sum of money to children who had achieved high grades in the village school. Following a new patriotic slogan, 'the whole Vietnamese nation turns to the sea' (cả Việt Nam hướng về biên), these women told me that they considered Lý Sơn Island to be the 'navel of the nation' (rôn bao của cả nước Việt Nam) and wanted to express their solidarity with local fishermen, whose months-long detention by China had been widely covered in Vietnam's national media. In Vietnam's traditional conception of the human body, the 'human body [is] a microcosmic reproduction of the vast dynamic forces at work in the universe' (Marr 1987:28), and the navel is considered the centre of the body. By calling Lý Sơn Island the navel of the nation, the erstwhile 'excentric' island has become the imagined centre of the country's geo-body.

How could a marginal place such as Lý Sơn Island become the nation's navel in so few years?

\section{Introduction}

Although there are historical records of the presence of Lý Sơn Islanders on the Paracels acting on behalf of a Vietnamese polity (see Lê Quý Đơn 1972; Bộ Ngoại Giao Uỷ Ban Biên Giới Quốc Gia 2013), the conflict with China over the South China Sea has opened up a new maritime frontier that did not exist before - at least not in the same manner. Back in 2006 when I carried out my doctoral fieldwork, 
few people had heard about Lý Sơn, and I observed few Vietnamese or foreign tourists visiting the island. However, eight years later, the conflict over the Paracel (Hoàng Sa) and Spratly (Trường Sa) archipelagos, with repercussions at local, national, and international levels, had inscribed the island at the centre of Vietnam's history and geography, and as the destination for thousands of Vietnamese tourists from all over the country. For many Vietnamese, the island was at the centre of a re-imagined map of the nation's territory, which now included both the land and the sea. Considered as a historic and contemporary stepping stone to the far-flung Paracels, Lý Sơn found itself in the middle of Vietnam's imagined maritime and territorial geo-body, as brought out, for instance, in iconographic depictions of Vietnam's map in daily televised weather reports. Lý Sơn thus became a figurative cartographic navel of the national geo-body.

The reason for this discursive connection between Lý Sơn and the Paracels can be traced back to the sixteenth and seventeenth centuries, and throughout the nineteenth century, when specific seafaring communities, including from Lý Sơn, were given the right to collect goods from wrecked ships in exchange for the best share of the spoils for Vietnam's rulers, thus giving both rulers and fishermen a material stake in and presence on the Paracel islands (Wheeler 2006). This connection was formalised through the Hoàng Sa (Paracel) navy, which consisted of sailors recruited from Lý Sơn Island (Lê Quý Đơn 1972:210). Many of the Hoàng Sa sailors died at sea and their bodies were never returned to their relatives, giving rise to special ritual and memorial practices in Lý Sơn.

In the context of tensions with China over competing claims over the South China Sea during the early 1990s, the Vietnamese State turned its attention towards Lý Sơn as a valuable source of information about the sailors of the Hoàng Sa and Trường Sa navies (Roszko 2010). A few years later, it issued a directive establishing a memorial site for the two flotillas. Facing rival claims from China to sovereignty over the archipelagos, the Vietnamese Party-state chose to frame its strategy not in economic terms, but with reference to historical and emotional stories of Vietnamese sailors who had sacrificed their lives at sea. Through gradually revealed family genealogies which are expected to shed new light on Vietnam's putative long-standing sovereignty in 
the Paracel and Spratly archipelagos, members of Lý Sơn lineages have worked hard to recentre their marginal(ised) locality on the imagined map of the national territory - this time including the sea.

Historian Dian Murray (1988:4) points out that uninhabited islands constituted little concern for neo-Confucian states such as China or Vietnam, where sovereignty was typically defined in terms of human habitation and social organisation. According to this view, the Paracels and Spratlys were considered by Chinese and Vietnamese imperial governments as a maritime hazard for safe navigation rather than as an integrated part of national territory. This changed in postcolonial times. The colonial encounter had a transformative effect on many Asian states, which were pushed to recognise the need for creating their own national geo-body - both the territory and the nation - through mapping, and thus crafting an outline of the map as a national symbol (Winichakul 1994; Roszko 2015). The current conflict with China over the South China Sea evokes strong emotions in Vietnam, where many people assert feelings of affection for the 'ancestral' grounds of the - largely uninhabited and uninhabitable - islands and islets of the Hoàng Sa (Paracels) and Trường Sa (Spratlys). As I describe elsewhere, repeated Chinese seizure of Vietnamese vessels and the detention of Lý Sơn fishermen has been widely covered in Vietnam's mass media in the last five years, adding fuel to an already heated mediated debate about the disputed archipelagos in the South China Sea (Roszko 2015). At the same time, by designating officially approved spaces for expressing feelings of national pride, the Vietnamese state uses all possible means to encourage Vietnamese people's identification with the expansion of Vietnam's territory to include the contested waters in the South China Sea.

Against the backdrop of the South China Sea dispute, this chapter examines what kind of shift in subjectivities is required of Lý Sơn people to navigate the state's project and new economic opportunities that have emerged with the growing national interest in the island's historical and cultural heritage. How does the Lý Sơn community actively recentre itself on the imagined map of the nation's geo-body in its desire to become part of the modern world? As I demonstrate, people in nationally significant sites such as this have their own agendas and interpretations of history that favour local identities over all-embracing state visions ( $\mathrm{O}^{\prime}$ Connor 2003:271). In order to capture these processes at work, I open my discussion by exploring 
territorial imaginaries associated with 'Vietnameseness' and spiritual and hierarchical boundaries between two modes of life - farming and fishing. In the subsequent section, I focus on the islanders' gradual marginalisation in post-revolutionary Vietnam and their various aspirations to break their provincial status as fishermen by claiming the identity of traders and explorers as a way of life. In the final section, I analyse how Lý Sơn villagers position themselves in the context of Vietnam's novel rhetoric that redefines the country from a rice-growing culture to a maritime nation. Ultimately, I suggest that islanders seek to produce their own version of locality against the backdrop of the territorial dispute and their victimisation by the Chinese coastguard, widely projected in the national media.

\section{Territorial Imaginaries}

Colonial sources produced influential territorial imaginaries of Vietnam, centred on the terrestrial rice-growing Red River Delta as 'the cradle of Vietnamese civilisation'. This era is also the source of the cliché of the Vietnamese village as a politically autonomous, socially homogenous corporate community surrounded by a hedge and rice paddies (for example, Gourou 1936, 1940; McAlister and Mus 1970; Kleinen 1999). Moreover, the classic tripartite division of Vietnam into North, Centre, and South, metaphorically characterised by " two rice baskets on a pole" - to describe the agrarian rich North and South held together by the poor but hard-working Centre' is still alive in many historical accounts (Wheeler 2006:129-130). Keith Taylor (1998:971) has spoken against the 'pan-Vietnamese village morphology' that produces the hierarchy defined as 'Vietnamese' and points out different ways of acting Vietnamese that existed through space and time. Taylor's (1998) critique of representations of Vietnamese history, culture, and territory as affirming unity and continuity is echoed in the work of Charles Wheeler (2006), Li Tana (2006) and John Whitmore (2006) and their attention to the coast. By conceptualising the littoral as a fluid rather than solid zone they offer a new perspective on Vietnamese society seen from the sea. Like the littoral, which is in a constant state of flux, this society must be seen as fluid and flexible as well (Pearson 1985, 2003). 
My own ethnographic work in coastal communities shows that potent intersections of religion, economy, politics, and ecology are particularly visible in such a contact zone where the state struggles to establish and increase its presence (Roszko 2011). The very idea of 'Vietnameseness' tends to underplay the regional, historical, and cultural differences, and to marginalise places such as Lý Sơn Island that are seen as representing an extreme, unusual, and unsettled situation that does not stand for the imagined Vietnamese territory and nation. The spatial marginality and ambivalence of such communities remains a major concern of the state, which tries to incorporate them through various cultural agendas and development programs, such as the already mentioned patriotic tourism. For instance, after several ports in China started to operate regular tours to the disputed Paracel archipelago, Vietnam's Ministry of Culture, Sports and Tourism responded by approving an ambitious project aiming to develop Vietnam 'into a strong sea-based country, enriched by sea' and protect national sovereignty. ${ }^{2}$ In the context of an imagined or real threat from China, many urban Vietnamese book tours to unpopular islands that were previously only loosely connected to the Vietnamese geo-body in order to - at least once in their life - experience the fatherland as seen from the sea. ${ }^{3}$

In response to uneven access to education, healthcare, or basic infrastructure, along with China's exclusionary claims on resources in the South China Sea, Lý Sơn people appropriate and capitalise on these national and geopolitical narratives in order to reproduce and relocate their locality in a desired way. The commemoration related to Hoàng $\mathrm{Sa}$, which more recently has received the status of 'national heritage', provides the opportunity for Lý Sơn villagers to demonstrate the historical and communal value of their genealogies and temples, and reshape and redefine their local narratives and social identity beyond the category of fishermen. According to local family records (gia phả) the first 15 Việt families came from the mainland in 1609, divided land between them, and established two villages, An Hải and An Vĩnh,

2 www.hanoitourist.com.vn/english/sea-travel/1817-sea-and-islands-a-driving-force-for-vietnam-tourism-development, accessed 4 September 2015.

3 english.vietnamnet.vn/fms/travel/12151/marine--island-tours-chosen-to-show-patriotism. html, accessed 4 September 2015. 
which nowadays form two communes. ${ }^{4}$ However, a source of anxiety for the islanders was the awareness that the Việt people on Lý Sơn Island were only the latest residents in a long history of settlement, and that archaeological evidence indicates that the Cham civilisation was present prior to the Việt arrival on Lý Sơn. Islanders assuaged such unsettled feelings by seeking to convey a sense of genealogical continuity with the mainland. During my conversations with the islanders, many of them betrayed a sense of awkwardness about the previous Cham presence, which is indisputable taking into account archaeological evidence. A Lý Sơn villager told me:

In the past, Bình Thuận was the place of origin for the Cham people but from there they spread to central parts entering Đà Nẵng and Quảng Nam. In Lý Sơn there was not so many of them, so [the land] out here was intact. There was no one to have an exchange with at all. For that reason in the sixteenth and seventeenth century the Việt people occupied Champa and stayed there. Well, back then, people from all provinces were moving in and out ... to other provinces. There were also people here [on the island] and the Cham also came here but then [Việt] occupied the islands. After that [Cham] did not come here anymore, they were not able to [laughing] ... The Việt caught crabs, fish and snails which they ate through the day to survive. When more Việt occupied the island and stayed here the civil harmony began with Champa people.

When I asked what he meant by the 'civil harmony with Champa', he replied:

Still, there were a few Champa people here, they lived on this land. After those regarded as Champa died, they did not enter the island anymore, they were gone so the Việt people flocked together here.

The passage quoted above is not an isolated example of the awkwardness associated with the previous Cham presence on the island. It reveals an immediate defensive reaction by islanders who tried to convince me of the absence of Cham people at the time when their ancestors arrived on the island. Despite the historical evidence that Champa consisted of several coastal states which occupied the south-central

4 See, for example, Gia Phả - Hộ Võ Văn (Family annals - Hộ Võ Văn) kept by the Võ Văn lineage, An Vinh Commune, Lý Sơn District, Quảng Ngãi Province or Gia Phả - Hộ Phạm Văn (Family annals - Hộ Phạm Văn) kept by the Phạm Văn lineage, An Vĩnh Commune, Lý Sơn District, Quảng Ngãi Province. 
coast of Vietnam from the end of the first millennium BC (Southworth 2004; Vickery 2009; Hardy 2009), many islanders maintained that the Cham were originally concentrated only in the southern part of Vietnam, in present-day Bình Thuận Province. Many villagers claimed that those Cham who stayed on the island gradually vanished and, generally, the Việt people outnumbered them. In this way, Lý Sơn people wanted to clear up any doubts about their identity, the rights over the land, or possible violence in the settlement process on the island. Yet, the surnames such as Mai, Đinh, Tiêu, etc., suggest that the Vietnamese migrants on Lý Sơn Island intermixed with the Cham natives (very few of whom still lived in the area). In the process masking their Cham origin - the descendants of these inter-ethnic marriages absorbed and retained most of the beliefs of the agrarian villages from which their Viẹt forefathers had come.

While contemporary residents took possession of islands as Việt territory by means of a Việt-centric settlement history, villagers were grappling with the problematic notion of Cham predecessors, which unsettled their sense of territoriality. Indeed, as some authors argue, control over territory 'is not only about use or power; it is also about meaning, claiming, consolidating, legitimacy' (Vaccaro, Dawson and Zanotti 2014:3). Intriguingly, we obtain a very different understanding of how villagers emplace themselves in Lý Sơn history by considering their ritual relations with the Cham spirits that are to this day worshipped in many temples on the island. The ritual relationship with these spirits, predicated on the existence of a more powerful spiritual domain, was maintained through the ritual 'buying or renting land' (lễ tả thô) (Li Tana 1998:131; Tạ Chí Đài Trường 2005:264). Right into the twentieth century, the inhabitants of Lý Sơn performed a 'ritualised bargain' through a local 'sorcerer' with a Cham ancestral couple, Chúa Ngu Ma Nương, and made lavish sacrifices in order to keep the land fertile (cf. Li Tana 1998:131; Tạ Chí Đài Trường 2005). One of the oldest inhabitants of Lý Sơn Island described the ceremony concerning land ownership in the following words:

In the past, the North of Lý Sơn belonged to the Cham Kingdom [Chiêm Thành]. Our Kinh forefathers fought with the Cham Kingdom who were defeated and had to leave their land. The land remained and it was sacred [linh thiêng]; if our ancestors who wanted to inhabit it refused to worship them [the Cham deities] they would bring serious illnesses upon the village. That is why the forefathers installed an altar 
[on the old Cham territory] for a wife and husband Chúa Ngu Man Nương. The couple managed the land and every five years the village organised the ritual of 'request for land' during which many oxen and buffalo had to be offered to keep peace. The ceremony was great and lasted several days and nights. The sorcerer [phù thuỷ] was invited too. He called the couple and asked them if they were satisfied with the offerings. If they said 'yes' they could stop but if they said 'no' they had to continue to make sacrifices of animals. The land belonged to them, without the offerings the village would be punished. If the husband required five pigs they would give him exactly five pigs. When queried about this they responded: 'the husband was easygoing but to satisfy his wife was very difficult!'

By performing the large ceremony for the Cham spirits, such as the Uma Goddess and Chúa Ngu Ma Nương, ${ }^{5}$ the newcomers established themselves not only as rightful patrons of the new land but also tacitly apologised for taking this land away from the Cham natives. As the new owners of the territory they ritually accommodated the fact that other inhabitants once ruled over the land and its fertility. Through ritual procedures the spirits were pacified and incorporated into the pantheon of the new dominant community that gained local power.

The new experience of the sea and the encounter with Cham civilisation prompted the Việt on Lý Sơn Island not only to adopt foreign spirits and beliefs into their own religious practices but also to willingly experiment with the material culture of their predecessors. Việt migrants learned seafaring techniques from the Cham and even the structure of their ships followed Cham principles (Li Tana 1998:112; Pham, Blue and Palmer 2010; Pham 2013). Local family annals (gia phá) provide information from the seventeenth to the nineteenth centuries that, due to the excellent seafaring capacity of the islanders, many were recruited by the feudal state to collect precious sea products and goods from wrecked ships in the Paracel and Spratly archipelagos. The eighteenth-century Vietnamese historian Lê Quý Đôn (1972:210) reported the case of Vietnamese sailors who were allowed to move to Lý Sơn and were granted royal concession to explore the sea. Such practices were not unique to Vietnam, but also took place in other regions of Southeast Asia. In his interesting account on eighteenth- and early nineteenth-century migration and

5 Uma Goddess is the name for the Hindu Great Goddess Paravati, usually associated with mountains. Chúa Ngu Ma Nương is a Cham spirit of a husband and wife. 
trade practices of 'sea people' in Southwest Kalimantan, Atsushi Ota (2010:69) writes that during this period many migrants, called 'pirates' by Europeans, established their communities in the coastal areas and 'were engaged in various profitable activities such as trade, fishing, and cultivation, supplemented by occasional raids on traders, fishermen, and the villagers'. By calling these maritime migrant communities 'sea people', Atsushi Ota (2010:69) makes an interesting point that those communities were 'within the political reach of states and settled under state rulers' approval, but they were not completely politically integrated, maintaining privileges in certain activities, such as settlement in certain places and plundering'. This resembles the case of Lý Sơn, with its loose connection to the mainland's political apparatus. As already mentioned, this connection was formalised as the Hoàng Sa and Trường Sa navy, consisting of villagers recruited from Lý Sơn Island who operated in the vicinity of the Paracels and Spratlys, which today constitute the fishing grounds of Lý Sơn fishermen (Lê Quý Đôn 1972:203, 210).

\section{The Dichotomy Between the Land and the Sea}

Trần Quốc Vượng (1992:29) notes that in pre-colonial and colonial Vietnam, fishing was a despised occupation and fishermen constituted one of the most marginalised groups in society. Landless, without roots in the village and living in areas close to the sea and rivers, fishermen were discriminated against and deprived of the spiritual and material means offered by the village. The dichotomy between the land and the sea that constitutes Lý Sơn society is expressed in the two emic terms: làng and vạn. Traditionally, làng or 'village' constituted the territorial unit of Vietnamese society, with the political and ritual system localised in the dinh (communal house), and represented a land-based lifestyle. In the dinh, villagers spiritually ensured good harvest for the upcoming year through the worship of those who first broke the land under the plough (tiền hiền) and the founders of the village (tiền hậu). ${ }^{6}$

6 In central and southern Vietnam, communal houses were characteristically erected in honour of the tiền hiền and the tiền hậu: those who first broke the land under the plough and the founders of the village. Where the communal house was a northern dinh it was a shrine for the village guardian spirit. The guardian spirit of the village, or thành hòng, worshipped in the northern dinh could be either a historical or a mythical person. 
Generally, in central Vietnam, van referred both to a self-ruling fishing organisation and to a territorial unit with its own religious system localised in the lăng, a temple for the cult of a seafaring guardian spirit - the Whale. The fact that lăng means 'tomb' speaks volumes about fishermen's concerns, as if through propitiating the Whale Spirit they sought protection rather than seeking to ensure and control the fertility of land and, hence, the village.

Lack of arable land and inability to grow rice is an important detail that sheds new light on the formation of categories such as làng and van in Lý Sơn. In the face of serious physical constraints to growing rice, islanders still tried to reproduce the hierarchical division between farmers and fishermen that they knew from the mainland. Coming from the northern coast of Thanh Hóa, Nghệ An, and Hà Tĩnh, some of the 'founders' and 'great lineages' might have had the lower status of fishermen, but in the new setting, by taking advantage of being first, they established themselves as a superior lang. The recognised descendants of the 'founders' formed dominant lineages and an unofficial channel of grassroots administration - chiefs of hamlets (xóm) and sub-hamlets (lân) — that operated as 'patrilineages' of the village. Other lineages that were ranked alongside the 'founders' but did not win the same power were those whose precursors came shortly after the founders; these lineages were called tộc lớn, or 'great lineages'. This hierarchical stratification survives on the island until today and is displayed in religious and ritual practices. All of these groups recorded their genealogies (gia phả) in the ancestral halls of individual lineages. Others, who might have been fishermen or peasants, were not admitted to the dinh order and did not share equal rights as village members because they arrived much later than the 'founders' and 'great lineages' and did not have access to free land. They were required to obtain permission from the 'founders' or 'great lineages' to buy a plot of land and build a house on the territory of the village, but even in such cases they were not considered legitimate village members. Denied village membership, they joined forces and formed a van with its own civil code, although still subordinated to the village.

In contrast to mainland central Vietnam, where fishing communities occupied sandy dunes and could be easily distinguished from agricultural villages with their surrounding rice fields, fishing and farming settlements on Lý Sơn Island merged because of the lack of 
arable land for rice cultivation. More precisely, the two 'municipalities' of An Vĩnh and An Hải were established in the seventeenth century as two làng, but shared their territory with two vạn: Vĩnh Thạnh and An Phú. Vĩnh Thạnh vạn was positioned within the territory of An Vĩnh village, while An Phú vạn overlapped with An Hải village. This arrangement survives today. Those who formed a làng, however, could not claim superior status on the basis of investment in rice cultivation; nor could they produce the crop that would rescue the village from starvation in times of famine. Unable to keep strict physical boundaries between the làng and the van, làng members of the two villages nurtured these separate categories through ritual and ceremony, and through claims that their ancestors were the first settlers on the island who tamed the new 'wild' land and founded the villages.

Drawing on the annals and local narratives, we know that the Hoàng Sa and Trường Sa navies that collected and traded goods from wrecked ships consisted of those who were members of the founding lineages and those who belonged to the organisation called van. Moreover, according to An Vĩnh temple's records, the vạn in Lý Sơn was more than just a fishing organisation; above all it was a trading organisation (van giao thương), a point that I will develop in more detail later. ${ }^{7}$ The popular saying that fishermen 'soak up wealth like a sponge' (giàu bọt nước) hints at the perception that their profit was not morally justified when compared with the hard work of preparing the soil for cultivation (Nguyễn Duy Thiệu 2002:118). Coastal settlements were seen as the frontier of pirates and smugglers who could always find a good hideaway somewhere along the South China coasts (see, for example, Watson 1985; Murray 1987; Kleinen and Osseweijer 2010). Michael Pearson (2003:6) wrote:

[p]irates and fisherfolk are ubiquitous, the former to be seen as macroparasites, human groups that draw sustenance from the toil and enterprise of others, offering nothing in return, the latter equally predatory, for unlike peasants they extract but do not cultivate, take but do not give.

7 See the Hán-Nôm document of Vĩnh Thạnh vạn in An Vĩnh commune, Lý Sơn Island. 
In this sense, fishermen were regarded by the agriculturalists as a 'world apart', a group living in the margins of society, 'savages' and 'barbarians', who did not really represent the traditional Vietnam (Nguyễn Duy Thiệu 2002).

In his classical monograph on Malay fishermen, Raymond Firth (1964) demonstrated that in coastal areas, fisherfolk often live side by side with people of other occupations, including farmers with whom they maintain economic and frequently intimate relations. Pearson (1985:3) goes a step further by stating that 'land and the sea intertwine in complex and various ways', arguing that we must avoid seeing the people living on the shore as totally land- or sea-oriented. Indeed, Lý Sơn's cosmology looks both to the mainland and to the sea as sources of livelihood and as cosmological and sovereign centres. Yet the example of Lý Sơn shows that they dichotomise two modes of life - farming and fishing - even though in everyday life they might mix the two activities. The two vernacular terms - làng and van - appeared in almost every conversation with villagers, indicating that they recognise a social difference between the land and the sea. The distinction between the two territorial domains was manifested in the erection of two separate temples — dinh and lăng — which marked spiritual and hierarchical boundaries between the land-based village and the fishing community.

Nevertheless, such distinctiveness between sea and land activities preserved in the social and religious organisations of the Lý Sơn society does not exclude the possibility that these two types of community are in a constant state of flux. The example of Thiên Y A Naa Vietnamised Cham Goddess of Pô Nagar who is believed to secure the livelihood of the fishermen on the seashore - well illustrates this phenomenon. Whenever I attended anniversary ceremonies for Thiên Y A Na in An Hải village, I was always astonished by the large number of fishermen who visited her temple and took part in religious observance. While in this temple, the làng carried out an important ritual aiming to ensure the fertility of the land. I also witnessed fishermen sacrificing to the goddess - once they gave two, or even three, fine pigs. They explained that when the goddess blessed them with good catches or they escaped a Chinese coastguard they gave back to her more than was expected. The ceremonies always took place in the late evening, enduring for many hours and ending with a feast before the sun broke the darkness. 
However, the làng was not always happy with the ostentatious sacrifices made by the van, and in some cases tried to regulate this matter. According to local narratives, in Lý Sơn at the beginning of the nineteenth century, farmers found a whale beached on the shore just opposite the temple of the Goddess of Five Elements (Bà Chúa Ngũ Hanh) which belonged to the village An Vĩnh. The villagers decided to include the seafaring deity in their spirit pantheon. The fishermen's organisation of Vĩnh Thạnh protested and claimed rights to the beached whale. However, the farmers refused to yield and they strongly believed that the Whale Spirit chose their village to send rain in time of drought and to improve crops. Subsequently, the two communities of farmers and fishermen reached a compromise by building two separate temples called the Outer Dune Temple (Lăng Cồn Ngoài) and the Inner Dune Palace (Dinh Cồn Trong) to venerate the Whale Spirit, which was revered by fishermen and farmers alike under his full name 'Great and Cruel General of the Southern Sea' (Nam Hải Dạ Sa Đại tướng quân tôn thần). It was decided that the fishermen's anniversary celebration would precede the one organised by the farmers but it could not be held without the presence of the village elder - the ritual master of high sacrifice and representative of the founding lineage and hence a farmer — as a sign of the van's respect for the village. In June 2007, I took part in the ceremony organised by the van. I witnessed that the van was not allowed to offer a pig, as this sacrifice was reserved for the làng, and instead was only permitted to present a chicken to the divinity.

In saying that the islanders cognitively dichotomise the sea and the land, we should not associate their sense of territoriality with hierarchy, as enshrined in a permanent and immutable situation and structure (Kirsch 1973:35). Lý Sơn society is subject to a continuous process of change due to the ever-changing ecological, political and social conditions of its environment. Thus, the structure of the làng and the vạn in Lý Sơn is not permanent and static but constantly adapting to current situations. With a growing global demand for marine products and the global consequences of the South China Sea dispute, fishermen started to play a more important role in the village ritual domain to which the van had no previous access. Like in the past, when the feast in the dinh served to increase status differences within the village, today the van uses the same means in order to earn 'permanent prestige and status relations' as well as social recognition 
(cf. Kirsch 1973:17). Renovating temples, appropriating the traditional right of the agricultural village to sacrifice pigs, and sponsoring village agricultural rituals became means of displaying their ritual 'potency' and thus their growing status in the Lý Sơn community. Each lavish sacrifice made by fishermen in agricultural temples served as evidence of their good catches and their material well-being and hence their spiritual 'reward'. By resisting the exclusive ritual control of the lang, they turned the tables on the old hierarchy.

This recent enhancement of fishermen's economic position vis-à-vis the farmers and their ritual investment in agricultural temples reveals the complexity of local territorial imaginaries and the dichotomy between the land and the sea. It also suggests that fishermen are not just a disadvantaged group, but that they exploit the situation in order to demonstrate and cultivate their prestige in response to the changing political and economic context. This observation goes to the heart of Taylor's (1998) argument that different modes of acting Vietnamese exist through time and terrain. Instead of looking at Lý Sơn villagers exclusively through the lens of the homogenising narratives of the nation, region, or historical process, it is worth remembering that they constitute not monolithic but rather heterogeneous entities entangled in complex relations in which they construct themselves within and across international, national, and local interests (Appadurai 1996).

\section{Cosmopolitan Connections}

Lý Sơn villagers proudly talked about their ancestors' engagement with other societies, and their extraordinary mobility and adventurous explorations to contest and change their present status as a remote or 'sea-locked' and 'outlandish' fishing community. Indeed, mobility and commercial networks between Cham, Chinese, and Việt across the South China Sea were long standing. ${ }^{8}$ Prior to Việt colonisation in the seventeenth century, Lý Sơn had been an important part of a network of wells providing fresh water to Cham sailors and foreign ships (Hardy 2009). Throughout the seventeenth, eighteenth, and nineteenth centuries, the Hoàng Sa and Trường Sa sailors capitalised on various cosmopolitan and commercial links in the South China

8 For the region of the Mekong Delta, see Taylor (2007). 
Sea by gathering gold, silver, swords, ivory, porcelain, cloth, wax, and other goods from the wrecked ships in the Paracels and Spratlys, and supplementing them with a large quantity of mother of pearl, snail, tortoise, and sea cucumber, which were submitted to the royal court in Huế. The sailors were allowed to keep a significant part of the harvested marine produce for their own profit (Lê Quý Đôn 2006:155). The impressive and well preserved ancestor house built during the reign of the Minh Mạng Emperor (1820-41) by the family of Mr Tư (b. 1930) ${ }^{9}$ - the uncle of my host on Lý Sơn - bears testimony to the extraordinary profits derived from that trade and extensive maritime networks that connected Lý Sơn villagers and Chinese. During their voyages to the Paracels, the Hoàng Sa and Trường Sa sailors occasionally met Chinese fishermen on the high seas and exchanged information (see, for example, Lê Quy Đôn 1776:82b-85a in Nguyễn Q. Thắng 2008). In the nineteenth and twentieth centuries, some Fujianese or Hainanese who ventured into the Nanyang region (present-day Singapore, Malaysia and Indonesia) to procure their catches of the sea cucumber (hải sâm, bêche-de-mer) stopped in Lý Sơn to obtain fresh sweet drinking water and peanut oil for cooking. Mr Tư revealed that generations of his family had built their wealth on the lucrative trade that involved the sea cucumber - a highly appreciated delicacy among Chinese. For a long time, Lý Sơn villagers did not develop a taste for sea cucumber, but knew how to process the marine animal in order to sell the product in Hội An - a former Cham port that from the seventeenth century onward attracted many Chinese as well as Japanese, Muslim, and European merchants.

Under French colonial rule, the Hoàng Sa and Trường Sa flotillas ceased to exist, but the seafaring capacity and trading profession of the islanders enabled their voyages to the south where they continued to explore new markets and expand their world and networks through translocal and transregional trade. The Lý Sơn seashore and adjoining waters were rich in fish, snails, sea urchins, and sea cucumbers, and provided trade for many. As the vạn in Lý Sơn functioned as a trading organisation, islanders traded with the mainland and sold whatever they caught and farmed: beans, peanuts, and - most famously — fish sauce, peanut oil, and fishing nets made of a special tree fibre (cây gay) grown on Lý Sơn. An informant from Lý Sơn explained that in the 
1930s his late father had worked as a 'trader assistant' (lái phụ) for one of the boat owners (chủ tuyền) on the island, travelling southward on the winter monsoon and returning northward with the summer monsoon. In November (lunar calendar), the northerly wind began blowing and in the following few months Lý Sơn people sailed to Sài Gòn for the Lunar New Year. The trip south was to buy rice, which was essential for Lý Sơn people's livelihood. The father of my informant did not travel alone but was accompanied by a group of other sailing boats that followed him. En route, he made two important trade deals: he bought sugar (đường phên) in Quảng Ngãi and salt in Sa Huỳnh, and relied on established trade networks in Quy Nhơn, Nha Trang, and Hà Tiên. Disembarking in Sài Gòn or Cà Mau, he and the rest of his crew offered themselves as labourers to the French or Chinese, which gave them additional income for the purchase of rice. During March, the wind began to change course to a northerly direction, signalling the time for the return trip. In early summer, with a full load of rice, the group sailed in a northerly direction along the coast, passing different ports on the way. Since medicinal plants (thuốc nam) were highly sought after by islanders, Cham traders were welcomed on board, embarking at the port of Bình Thuận and remaining on board until reaching the island. The father of my informant would stop again in Sa Huỳnh to buy salt for resale in Lý Sơn. However, reaching home did not mean that the voyage was complete. Taking advantage of the southerly wind, he would resume his journey northward through the ports of Hội An and Huế where he would typically purchase blocks of jackfruit wood, for building ancestral houses, and Chinese porcelain, which was highly sought after by Lý Sơn islanders.

The outbreak of the First and the Second Indochina Wars brought new political and economic pressures to the Lý Sơn people, who were trapped between two forces: the National Liberation Front and US troops. The strategic location of the island was used by the Vietnam Naval Forces - a command of the US Navy - to control passing ships and trawlers in the South China Sea but also by communist guerrillas to hide stolen weapons, for example. Lý Sơn fishermen were occasionally used by the Vietnam Naval Forces in military missions to the Paracels. However, in contrast to the mainland, Lý Sơn's geographical position enabled it - to some extent - to avoid the turmoil of war. Importantly, most of the island's religious structures survived the two Indochina wars, giving both the provincial authorities and the local 
community a clear stake in recovering local commemoration of Hoàng Sa and Trường Sa sailors and applying for national recognition of this ceremony. In the eyes of Lý Sơn villagers, this commemoration was testimony that they were not backward but using their trading skills and the seafaring capacity that connected them with the rest of the world. Forty-nine-year-old Lý described this in the following words:

Previously Lý Sơn people used to go on sailing boats and, I think, because of that, having only sailing boats they were still able to go to the Paracels. They kept sailing to the Paracels not because of the royal order, which at that time was just a small part of their activities, but because the Paracels were located on the Silk Road, the trade route of, for example, Chinese, Dutch, Spanish, Portuguese; all kinds of people were passing there, so they [Lý Sơn people] followed that route and its trade up to the Paracels. There the Hoàng Sa flotilla was responsible for collecting things such as guns, steel or porcelain ... I am telling you some families in Lý Sơn if they traded they would get very rich. Lý Sơn was very rich so that the guiding principle of Lý Sơn [people] in that time was 'to get rich one must do trade' [muốn làm giàu phải đi buôn], or, as they put it, 'without trade there will be no prosperity' [Phi thương là bất phú] with the meaning that in order to get rich you must engage in trading, so those in Lý Sơn who did trade were economically better off.

When Lý said that villagers went to the Paracels regardless of the royal order, he meant that the islanders always had to strategise and seek various opportunities to make a living. He later added that Lý Sơn fishermen would continue to go to the Paracels or Spratlys without consideration for the state's position for the same reason, because this is one of the very few options available to them to earn their living.

While Lý sentimentally talked about the previous economic cosmopolitanism of islanders and their prosperity, he also depicted the dramatic changes and desperate years brought at the end of the Second Indochina War. The islanders' mobility and trading networks were severely restricted after the reunification of Vietnam in 1975, particularly in the period of the collectivist subsidy economy which lasted from 1977-86. Lý Sơn villagers reported shortages of basic necessities such as rice, sugar, and salt, which had to be brought from the mainland. To sail to Quảng Ngãi they needed to obtain special permission from the local authorities. Such permission specified clearly how many days they were allowed to stay away. On the day of the trip, their names would be called loudly by the authorities 
and only after presenting a valid document would they be allowed to embark on the small motor boat. The islanders recalled that the boat was filled with more people than it could properly accommodate, and many were forced to remain crouched or in an uncomfortable position for eight or more hours until reaching Sa Kỳ. Villagers still managed to smuggle local products, such as garlic and onion, to sell on the black market in Sài Gòn in order to buy rice to take home. Hidden in baskets full of vegetables, the rice was then illicitly transported by the boat to the island. Villagers recalled that they had so little rice that they cooked it with sweet potato in order to fill their stomachs. It was during this period that Lý Sơn people sought to ensure their livelihood by capitalising on their seafaring skills.

In 1982, Mr Nha (b. 1948) was the first fisherman on the island to make a daring journey to the Paracels - using a simple administration map stolen from the local People's Committee office. Later in the same year he guided another seven fishing boats. Navigation systems or nautical charts were not available at that time, as the local government feared that fishermen might seek to escape the country by sea. Initially, in the Paracels, the fishermen caught mainly flying fish (cá chuồn) which could be preserved using salt, but one year later when the technology became more accessible, they expanded their fishing territories, catches and methods. Fresh fish from the Paracels and Spratlys was transported to Đà Nẵng, where ice was also obtained. However, along with the new market opportunities that appeared, most Lý Sơn fishermen chose to sell their catch to local women traders in Đông Ba market in Huế. In 1989, Lý Sơn's fish trade was ultimately moved to Sa Kỳ port - the closest point between the mainland and Lý Sơn - where it began to operate under the Border Guard Command (Công an Biên phòng) which provided the logistical facilities for the development of the local fish market.

In the early 2000s, due to regular fishing expeditions to the Paracels and Spratlys and a diving technology that uses compressed air, Lý Sơn fishermen were able to collect the sea cucumber in deeper waters, and the old trade in the Chinese delicacy underwent revival. With the booming fishing market, some of the Lý Sơn people who in the late 1960s and 1970s emigrated to Quảng Ngãi, Nha Trang, or Sài Gòn saw opportunities for profitable business. They bought marine products from Lý Sơn fishermen and sold these to exporters, often of Sino-Vietnamese origin. The exporters provided credit to these 
intermediate traders who, in turn, were able to connect with fishermen. Initially, the cargo of sea cucumber, shark fin and, occasionally, turtle and turtle-shell and sea urchin, was sent to urban markets in central and southern Vietnam for export to China and Cambodia, but more recent destinations include ports in northern Vietnam. In the north, out of sight of customs patrols, fish and various marine products from Lý Sơn are traded across the border at fishing villages of Móng Cái and transferred to Chinese fishing vessels at sea, or transported directly by Sino-Vietnamese traders to Guangxi, Guangdong Province, or to Hainan Island.

This thriving trade of marine goods has been caught between two opposing forces - the liberalisation of cross-border trade between China and Vietnam, and the simultaneous enforcement of borders on the sea. Already under French colonial rule, China had begun to show interest in the uninhabited islands of the Paracels and Spratlys, and to assert claims over them. But it was not until decades later, in 2001, that China first denied Lý Sơn fishermen rights of use to fishing grounds which for generations they had considered their own. In 1982 - the year in which Lý Sơn people recommenced their trips to the Paracels and deep-sea fishing began - the legal regime of an exclusive economic zone (EEZ) came into force as a new provision of the International Law of the Sea. Until then, national borders at sea did not concern Lý Sơn fishermen, but with the enforcement of the EEZ they found themselves accused of entering restricted zones illicitly. As the economic, political, and military powerhouse in the region, China's expansion of an exclusive coastal economic zone resulted in the enforcement of a seasonal fishing ban, the seizure and detention of Vietnamese fishermen, and the destruction of their vessels by Chinese patrol ships. China's introduction of a map (in 2009) that engulfed virtually the entire South China Sea further exacerbated tensions and incidents in the region, in spite of a common history of commerce and exchange, and a shared understanding of marine life as common property (Roszko 2015). As the tensions over the Paracels and Spratlys worsened, occasionally erupting into anti-Chinese protests across the country, Lý Sơn villagers preferred to maintain a low profile for their trading activities with China.

The status of Lý Sơn as a restricted border zone impels Lý Sơn villagers to strategically preserve those memories of economic cosmopolitanism that figuratively bring the island closer to Vietnam's ancestry and 
fatherland, simultaneously obscuring those shared with the Cham or Chinese. In doing so, they selectively underline that Lý Sơn Island was not an isolated place, but one situated at the crossroads of the Silk Road trade routes that spanned China, Hainan, Nanyang, and the rest of the world. Articulating alternative accounts of their ancestors' engagement in long-distance voyages at sea, local markets, and commercial networks, Lý Sõn people conveyed an implicit protest against their dramatic domestication and reductive narrative representations brought about by a centrally planned economy after 1975 and the politicised South China Sea dispute. As a result, these proud and skilful sea navigators and traders with cosmopolitan economic networks - who once did not hesitate to advertise to the royal court in Huế about their risky but profitable operations at sea became reduced to mere fishermen.

\section{Staging Citizenship on the South China Sea}

Seeking to become part of the modern world, the people of Lý Sơn have begun to contest their island's marginal location and seek to represent it as a strategic link between Vietnam and the disputed maritime areas to the east. By claiming that they are historically and emotionally bound not only to their natal villages on the coastal mainland, but also to the dispersed islets of the Paracels where their ancestors worked and died during marine operations, they projected their own meaning of territoriality. In Lý Sơn people's highly localised perception of the nation's territory, the modern border line shifted from the island to the Paracels and Spratlys, expanding and making Lý Sơn a virtual centre of Vietnam's territory, now comprised of both land and sea.

Being marginalised and economically left behind after the re-unification of Vietnam in 1975, Lý Sơn fishermen and farmers aspired to be recognised as translocal and 'cosmopolitan' subjects whose identity in previous centuries was built on extensive trading networks, and the experience of far-distance travel and exploration, rather than exclusively on fishing. As Nina Glick-Schiller and Andrew Irving (2015) show, cosmopolitanism is an ongoing process that allows those who feel provincialised and marginalised to be attentive to global processes without compromising their local interests. In the case of Lý Sơn, recentring the country's geo-body became a matter of integrating the mainland territory, the two disputed archipelagos, 
the familiar system of ancestor worship, their cosmopolitan economic networks, and the sacrificed Hoàng Sa soldiers into a new rendition of the imagined nation.

Capitalising on a newly discovered patriotism among islanders and consciousness about protecting 'ancestral lands' in the 'East Sea', in 2014 the Vietnamese Ministry of Culture, Sports and Tourism selected Lý Sơn Island - considered a vanguard of Vietnam's sovereignty to host the national exhibition of Vietnam's and China's historical maps, under the slogan 'Paracel and Spratly Islands belong to Vietnam - legal and historical evidence'. Most of the maps presented at the exhibition in a local museum were collected from various antiquarian bookshops around the world by Trần Đình Thắng - a young Vietnamese who was born in Vietnam but raised in a foreign country. With the aim of raising morale among local fishermen and local soldiers stationed on the island, the exhibition on Lý Sơn was marked by the attendance of representatives of the Vietnam Naval Forces, central and local state authorities, and guest of honour Trần Đình Thắng. The event was accompanied by a staged performance, including dance and patriotic songs, and widely broadcast in the national media.

Until recently, the region of the Red River Delta in Vietnam was seen as the undisputed cradle of civilisation and representative of Vietnam's 'authentic' wet rice culture. However, the international debate over the South China Sea caused a significant change in rhetoric in Vietnam which redefined Vietnam from a rice-growing culture to a maritime nation (nước biến). Discursively, these territorial and mental shifts were marked by stories about the most recent 'turn towards the ancestral sea islands' (hướng về biển đảo quê hương) and the idea of Vietnam as a 'nước biển' (literally 'sea country', but more accurately 'seaoriented country'), which is a contemporary invention of tradition that discursively places Vietnam in Tony Reid's (1999) Malay World. Propaganda posters recently arranged at the front entrance to the local museum on Lý Sơn Island are part of that effort. The most interesting slogans proclaimed: 'Vietnam is a maritime country' ('Việt Nam là một quốc gia biển'), 'The island is a home and the sea is a homeland' ('Đảo là nhà biển là quê hương'), and 'Each Vietnamese is a citizen of the sea' ('Mỗi người Việt Nam là một công dân biển'). While fishermen had previously been portrayed mainly in terms of socialist production - next to agriculture and forestry - the most recent Vietnamese state rhetoric turns Vietnamese fishermen into the heroic vanguards 
of national sovereignty in the 'East Sea'. Novel expressions of national identity and citizenship can also be seen in T-shirts bearing the slogan 'Vietnamese nation is determined to preserve each plot of the Vietnamese land and sea islands' ('Dân Tộc Việt Nam Quyết Tâm Gìn Giữ Từng Tấc Đất và Biển Đảo Của Việt Nam'), or 'Vietnam turns toward the East Sea' ('Việt Nam hướng về Biền Đông'). These T-shirts became increasingly popular among many young Vietnamese tourists in Lý Sơn who wanted to publicly express their identification with fishermen and the sea.

I opened my paper with a vignette about a group of eight patriotic former policewomen who wished to express their solidarity with poor fishing families, who were suffering for the sake of the nation, through an act of compensation. Ironically, most of the families selected for the meeting with the former policewomen depended on agriculture and not the sea for their livelihood, as month-long fishing operations in distant waters required considerable expenditure on gear, vessel, fuel, and reserves of food. In spite of the diversity of livelihoods found on the island, the women saw its inhabitants exclusively through the prism of the highly politicised character of the South China Sea dispute. Pointing to a cultural and economic gap between those on the mainland and those on the island, they perceived the inhabitants of Lý Sơn as 'nothing but sea people' ('người dân biển thi thế thôi'), and knowing hardly anything beyond living off the sea (biết chi làm biển thôi). Without help from the state - which was, for these women, an educator and patron of progress - the coastal areas such as the islands could not be developed. The women contested the islanders' way of being Vietnamese, as certain customs on the island made them anxious - for example, they considered it unhygienic that many graves were located in the vicinity of human habitation. Although the women's mission was to encourage fishermen to 'cling to the sea, cling to the fishing grounds to defend national sovereignty' ('bám biển, bám ngu' trường để bảo vệ chủ quyền tổ quốc'), they agreed that one could hardly consider Lý Sơn to be an attractive place to live, let alone a tourist destination. One of the women said: 'A touristic place is one of rest, entertainment and fun but there is nothing here' ('nơi du lịch là nơi nghỉ ngơi, giải tri và vui vẻ và ở đây chẳng gì có'). Her remark about the islanders' pronunciation, which she found incomprehensible and odd, cast the islanders as somehow less authentically Vietnamese in comparison with the more 'representative' culture of northern Vietnam. 
Vietnamese tourists' image of Lý Sơn as a navel of the nation was very much shaped by national media and recent tensions between China and Vietnam over the disputed waters in the South China Sea. Moreover, the media publicised contradictory images: on the one hand advertising Lý Sơn as a holiday destination with charming beaches, on the other hand underlining the island's defence position and praising the extraordinary bravery of its inhabitants living under constant threat from China. As a result, many mainlander tourists imagined the island as a highly militarised place located somewhere in the vicinity of China, but soon experienced the absence of electricity ${ }^{10}$ and medical facilities, the conversion of beaches into garlic and onion fields, and the islanders' 'incomprehensible' pronunciation. Taken together, these elements contributed to the perception of Lý Sơn as remote: a geographical and cultural backwater more suitable for a short, single visit rather than a longer stay. Most tourists perceived the islanders as an undeveloped fishing community bravely standing at the forefront of national sovereignty, in the very middle of Vietnam's land mass and the sea, including the Paracel and Spratly archipelagos.

Lý Sơn people were aware of these various perceptions about them and that they were seen as strange, odd, and at times funny. They felt uncomfortable about mainlanders' remarks about their local accent. For example, while they tended to appreciate my adoption of their local pronunciation, they immediately warned me that I was not allowed to speak 'Lý Sơn language' on the mainland, because they sensed that mainlanders would make fun of them. While they understood that the island's location made it a vanguard of Vietnam's sovereignty, attracting thousands of tourists and opening new economic opportunities, they still became upset if the national media stretched this picture too far. They were afraid that it might scare tourists and give a wrong impression of the island as a dangerous place. They were especially wary of crowds of journalists and local researchers who spent only a day or two on the island, chasing stories about fishermen victimised by a Chinese coastguard, or chasing elders and their family records. An outspoken islander woman expressed her opinion that real poverty on the island rarely attracted attention. Another fisherman complained that some journalists lost interest when they learned that the damage

10 At the time of fieldwork, between May and July 2014, the installation of a submarine cable providing power supply to Lý Sơn Island was under construction. Electricity only became widely available on the island in October 2014. 
to his fishing boat came not from a Chinese coastguard but from a short circuit. Others who renovated old guesthouses or built new ones worried about their business and wanted the island to be seen as a modern, safe, and attractive place for tourists. Situated on 'a tricky double edge - both cutting and peripheral' (Chu 2010:26), Lý Sơn people worked hard to recentre their marginal(ised) locality within the categorical order of the modern nation-state's cartography (Malkki 1992) by projecting themselves as cosmopolitan subjects. While they willingly shared with other Vietnamese a sense of being a 'navel of the nation' by claiming a twofold status, as an integral part of Vietnam and as part of the Paracel archipelago, they searched for their own context in the process of constructing their place within the nation's historical narrative and territorial map.

\section{Conclusion}

In his analysis of the local consequences of the international conflict known as the Taiwan Strait Crisis on Jinmen Island, Michael Szonyi (2008) vividly shows effects of militarisation slipping into the daily life of people and individual imaginations. Yet, in cartographic iconographies of Vietnam, it is the sea and its islands that have become conspicuously visible in arenas as varied as posters, stamps, logos, and museum exhibitions. In these changing aesthetics of the nation, the continental landmass becomes ex-centric and the margins become centred, culminating in the rendition of Lý Sơn as the navel of the nation. The island became a symbol of heroic sacrifice in the name of all Vietnamese citizens, who started to identify themselves with the 'Vietnamese waters'. In the case of Lý Sơn, this aesthetic shift is accompanied not by militarisation but by a changing geography of affect (Navaro-Yashin 2007) by which people who have never been on the Paracels or Spratlys claim a deep emotional bond with these 'ancestral' places and the desire to defend their 'sovereignty'. This affect is performed in a wide variety of ways: walling Lý Sơn Island against Chinese; emotional demonstrations in the streets of Hà Nội or Hồ Chí Minh City against Chinese occupation of 'ancestral' seas; and mainlanders showing solidarity with islanders - supposedly victimised by Chinese vessels - through patriotic tourism, donations and cultural campaigns. The changing geography of affect creates new spaces for interaction not just between state and society, but between 
different ways of acting Vietnamese. The affect provoked by the 'ancestral land' of the deep sea, fishing practices, new maps of the national geo-body, new development plans, and a new style of patriotic tourism in Vietnam's coastal areas illustrates the multitude of ways in which people respond to local and global economic and political discourses. In this same sense, the submarine cable that connected Lý Sơn Island with the national grid and provided a steady power supply in 2014 has been rendered not only as an item of cultural and socioeconomic development, but as an act of maintaining security, national defence, and sovereignty. ${ }^{11}$

Thinking about the economic cosmopolitanism of Lý Sơn people requires recognition that cosmopolitanism is about various groups of people whose actions are situated in different political, economic, and social niches, and who are driven by contradictory goals. The islanders' expanding universe - embedded in and shaped by global competition for resources in the South China Sea - was largely based on their local experience of long distance commercial fishing and trading, which has been interpreted by a large part of the Vietnamese population as Lý Sơn's determination to exercise Vietnam's sovereignty. Indeed, Lý Sơn's fishermen and farmers began to tie their identity to the state emergency in connection with the Paracels and with Lý Sơn Island's geopolitical role in this international dispute. However, the narratives about Lý Sơn's translocal and transregional connections to the sea could be read as villagers' desire to go beyond the image of their heroic and geopolitical role in the South China Sea that reduces them to the 'suffering subject' (Robbins 2013). In their desire to be modern, progressive, and attractive for the tourist industry, they seek to stage their own roles in this global dispute. Even though they might complain about enclosures and appropriations of terrestrial and maritime commons, and about the way they are being depicted as uncivilised and not-quite-Vietnamese, they often embrace the opportunity to take centre stage and become the centre of the nation for the eyes of the world to see - if only temporarily. The domestication and instrumentalisation of maritime populations in performances of and for the nation paradoxically draws the periphery

11 See, for example, www.vietnambreakingnews.com/2014/03/contract-inked-on-powersupply-for-ly-son-island/, accessed 31 August 2015. 
into the centre. For a short-lived moment, Lý Sơn people could be confident that their dispossession can be read as a sacrifice - willing or unwilling — for being the navel of the nation.

\section{References}

Appadurai, Arjun 1996, Modernity at Large: Cultural Dimensions of Globalism, University of Minnesota Press, Minneapolis.

Atsushi Ota 2010, 'Pirates or Entrepreneurs?: Migration and Trade of Sea People in Southwest Kalimantan c. 1770-1820', Indonesia, vol. 90, pp. 67-96.

Bộ Ngoại Giao Uỷ Ban Biên Giới Quốc Gia 2013, Tuyển Tập các Châu Bàn Triệu Nguyễn về Thực Thi Chủ Quyền của Việt Nam trên Hải Quần Đảo Hoàng Sa và Trường Sa [Collection of Official Documents of the Nguyen Dynasty on the Exercise of Sovereignity of Vietnam over the Paracels and Spratlys Archipelagoes], Nhà xuất bản tri thức, Hanoi.

Chu, Julie Y. 2010, Cosmologies of Credit: Transnational Mobility and the Politics of Destination in China, Duke University Press, Durham and London.

Firth, Raymond 1964, Malay Fishermen: Their Peasant Economy, Routledge and Kegan Paul, London.

Glick-Schiller, Nina and Andrew Irving 2015, Whose Cosmopolitanism?: Critical Perspectives, Relationalities and Discontents, Berghahn, New York and Oxford.

Gourou, Pierre 1936, Les Paysans du Delta Tonkinois: Étude de Géographie Humaine, Éditions d'Art et d'Histoire, Paris.

Gourou, Pierre 1940, L'utilisation du Sol en Indochine Française, Centre d'Études de Politique Étrangère, Paris.

Hardy, Andrew 2009, 'Eaglewood and the Economic History of Champa and Central Vietnam', in Andrew Hardy, Mauro Cucarzi and Patrizia Zolese (eds), Champa and the Archaeology of Mỹ Son (Vietnam), NUS Press, Singapore, pp. 107-126. 
Kirsch, A. Thomas 1973, Feasting and Social Oscillation: A Working Paper on Religion and Society in Upland Southeast Asia, Cornell University, Southeast Asian Program, Ithaca.

Kleinen, John 1999, 'Is There a “Village Vietnam"?', in Bernhard Dahm and Vincent J. Houben (eds), Vietnamese Villages in Transition: Background and Consequences of Reform Policies in Rural Vietnam, Passau University, Passau, pp. 1-41.

Kleinen, John and Manon Osseweijer (eds) 2010, Pirates, Ports and Coasts in Asia: Historical and Contemporary Perspectives, ISEAS Publishing, Singapore; International Institute for Asian Studies, Leiden, Netherlands.

Lê Quý Đôn 1972 [1776], Phủ Biên Tạp Lục [A Compilation of the Miscellaneous Records When the Southern Border was Pacified], vol. 1, Phủ Quốc Vụ Khạnh Đặc Trách Văn Hóa, Saigon.

Lê Quý Đôn 2006 [1776], Phủ Biên Tạp Lục [A Compilation of the Miscellaneous Records When the Southern Border was Pacified], vol. 1, Nhà xuầt bản văn hóa thông tin, Hanoi.

Li Tana 1998, Nguyễn Cochinchina: Southern Vietnam in the Seventeenth and Eighteenth Centuries, Cornell Southeast Asia Program, Ithaca, New York.

Li Tana 2006, 'A View From the Sea: Perspectives on the Northern and Central Vietnamese Coast', Journal of Southeast Asian Studies, vol. 37, no. 1, pp. 83-102.

Malkki, Liisa 1992, ‘National Geographic: The Rooting of Peoples and Territorialisation of National Identity among Scholars and Refugees', Cultural Anthropology, vol. 7, no. 1, pp. 24-44.

Malkki, Liisa 1995, 'Refugees and Exile: From "Refugee Studies" to the National Order of Things', Annual Review of Anthropology, vol. 24, pp. 495-523.

Marr, David G. 1987, 'Vietnamese Attitudes Regarding Illness and Healing', The Vietnam Forum, vol. 10, pp. 26-50.

McAlister, John T. and Paul Mus 1970, The Vietnamese and their Revolution, Harper and Row, New York. 
Murray, Dian H. 1987, Pirates of the South China Sea 1790-1810, Stanford University Press, Stanford, CA.

Murray, Dian H. 1988, Conflict and Coexistence: The Sino-Vietnamese Maritime Boundaries in Historical Perspective, Center for Southeast Asian Studies, University of Wisconsin, Madison.

Navaro-Yashin, Yael 2007, 'Make-believe Papers, Legal Forms and the Counterfeit: Affective Interactions between Documents and People in Britain and Cyprus', Anthropological Theory, vol. 7, no. 1, pp. 79-98.

Nguyễn Duy Thiệu 2002, Cộng Đồng Ngư Dân ở Việt Nam [Fishers Communities in Vietnam], Nha xuất bản khoa học xã hội, Hanoi.

Nguyễn Q. Thắng 2008, Hoàng Sa Trường Sa Lãnh Thổ Việt Nam: Nhìn Từ Công Pháp Quốc Tế [Vietnam's Paracels and Spratlys Territory: The View from International Law], Nhà xuất bản tri thức, Hanoi.

O'Connor, Richard 2003, 'Founders' Cults in Regional and Historical Perspective', in Nicola Tannenbaum and Cornelia A. Kammerer (eds), Founders' Cults in Southeast Asia: Ancestors, Polity, and Identity, Yale University, Southeast Asia Studies, New Haven, pp. 269-312.

Pearson, Michael N. 1985, 'Littoral Society: The Case for the Coast', The Great Circle: Journal of the Australian Association for Maritime History, vol. 7, no. 1, pp. 1-8.

Pearson, Michael N. 2003, The Indian Ocean, Routledge, London and New York.

Pham, Charlotte 2013, 'The Vietnamese Coastline: A Maritime Cultural Landscape', in Satish Chandra and Himanshu Prabha Ray (eds), The Sea, Identity and History: From the Bay of Bengal to the South China Sea, Society for Indian Ocean Studies, Delhi, pp. 94-137.

Pham, Charlotte, Lucy Blue and Colin Palmer 2010, 'The Traditional Boats of Vietnam, an Overview', The International Journal of Nautical Archaeology, vol. 39, no. 2, pp. 255-277.

Reid, Anthony 1999, Charting the Shape of Early Modern Southeast Asia, Silkworm Books, Chiang Mai. 
Robbins, Joel 2013, 'Beyond the Suffering Subject: Toward an Anthropology of the Good', Journal of the Royal Anthropological Institute, vol. 19, no. 3, pp. 447-462.

Roszko, Edyta 2010, 'Commemoration and the State: Memory and Legitimacy in Vietnam', Sojourn: Journal of Social Issues in Southeast Asia, vol. 25, no. 1, pp. 1-28.

Roszko, Edyta 2011, 'Spirited Dialogues: Contestations over the Religious Landscape in Central Vietnam's Littoral Society', PhD thesis, Martin Luther University, Halle.

Roszko, Edyta 2015, 'Maritime Territorialisation as Performance of Sovereignty and Nationhood in the South China Sea', Nations and Nationalism, vol. 21, no. 2, pp. 230-249.

Southworth, W. 2004, 'The Coastal States of Champa', in Ian Glover and Peter Bellwood (eds), Southeast Asia: From Prehistory to History, Routledge Curzon, London and New York, pp. 209-233.

Szonyi, Michael 2008, Cold War Island: Qumoy on the Front Line, Cambridge University Press, Cambridge.

Tạ Chí Đài Trường 2005, Thần, Người, và Đất Việt [Deities, People and the Land of Việt], Nhà xuất bản văn hoá thông tin, Hanoi.

Taylor, Keith 1998, 'Surface Orientations in Vietnam: Beyond Histories of Nation and Region', The Journal of Asian Studies, vol. 57, no. 4, pp. 949-978.

Taylor, Philip 2007, Cham Muslims of the Mekong Delta: Place and Mobility in the Cosmopolitan Periphery, University of Hawaii Press, Honolulu; NUS Press, Singapore; NIAS Press, Copenhagen.

Trần Quốc Vượng 1992, 'Popular Culture and High Culture in Vietnamese History', An Interdisciplinary Journal of Southeast Asian Studies, vol. 7, no. 2, pp. 5-38.

Vaccaro, Ismael, Allan Charles Dawson and Laura Zanotti 2014, 'Negotiating Territoriality: Spatial Dialogues Between State and Tradition', in Allan Charles Dawson, Laura Zanotti and Ismael Vaccaro (eds), Negotiating Territoriality: Spatial Dialogues Between State and Tradition, Routledge, New York and London, pp. 1-20. 
Vickery, Michael 2009, 'A Short History of Champa', in Andrew Hardy, Mauro Cucarzi and Patrizia Zolese (eds), Champa and the Archaeology of Mỹ Sơn (Vietnam), NUS Press, Singapore, pp. 45-60.

Watson, James L. 1985, 'Standardizing the Gods: The Promotion of Tien Hou (Empress of Heaven) Along the South China Coast 9601960', in David Johnson, Andrew Nathan and Evelyn Rawski (eds), Popular Culture in Late Imperial China, University of California Press, Berkeley and Los Angeles, pp. 292-324.

Wheeler, Charles 2006, 'Re-thinking the Sea in Vietnamese History: Littoral Society in the Integration of Thuận-Quảng, SeventeenthEighteenth Centuries', Journal of Southeast Asian Studies, vol. 37, no. 1, pp. 123-153.

Whitmore, John K. 2006, 'The Rise of the Coast: Trade, State and Culture in Early Đại Việt', Journal of Southeast Asian Studies, vol. 37, no. 1, pp. 123-153.

Winichakul, Thongchakul 1994, Siam Mapped: A History of the GeoBody of the Nation, University of Hawaii Press, Honolulu. 
This text is taken from Connected and Disconnected in Viet Nam: Remaking Social Relations in a Post-socialist Nation, edited by Philip

Taylor, published 2016 by ANU Press, The Australian National University, Canberra, Australia. 